\title{
Mental disorders and quality of life in patients awaiting liver transplantation
}

\author{
Lívia N F GUERREIR0-COSTA ${ }^{1}$, José Edson 0 ARAÚJ0-FILHO², Roberta Ferrari MARBACK', \\ Ana Paula JESUS-NUNES ${ }^{1}$, Mychelle MORAIS-DE-JESUS ${ }^{1}$ and Lucas C QUARANTINI ${ }^{1,2,3}$
}

ABSTRACT - Background - Liver transplantation is the main therapeutic alternative for patients with advanced liver disease. These patients have high prevalence of psychiatric comorbidities that may negatively interfere in clinical outcomes and quality of life. It is not clear in the literature whether the different etiologies of hepatic disease have the same prevalence of psychiatric disorders. Objective - The aim of this study was to investigate whether patients in the liver transplant list showed differences in psychiatric characteristics, medical variables and quality of life among different etiological groups. Methods - This is a cross-sectional study that evaluates quality of life, psychiatric and clinical comorbidities through the application of validated questionnaires and instruments in 248 patients who were on transplant waiting list from 2010 to 2014, assisted in a University Hospital and in a Private Hospital in Salvador/Bahia, Brazil. The patients were evaluated through the Mini International Neuropsychiatric Interview (M.I.N.I. PLUS 5.0) and Medical Outcomes Short-Form Health Survey (SF-36). Results - The etiology of the most prevalent liver disease was hepatitis C virus. A prevalence of $50.8 \%$ of at least one mental disorder was identified. When alcohol abuse/dependence was excluded, the prevalence was $25.8 \%$. Mental health did not show a statistically significant difference in the diverse etiological groups, but a higher prevalence of psychiatric comorbidities was detected among women and younger than 40 years. No cases of psychotic disorders were detected, possibly by exclusion prior to listing. There was no difference in the quality of life domains in the different liver etiological groups. Conclusion - A high-prevalence of psychiatric disorders was found among all clinical conditions most associated with indication for liver transplantation. Attention is drawn to the absence of patients with psychotic disorders, which suggests that transplantation may not have been indicated for this group of patients. For these reasons, professionals caring for liver transplant candidates should be highly vigilant for the presence of mental disorders, regardless of the etiology of liver disease. Specialized care is recommended to minimize the early exclusion of patients with no other therapeutic possibilities, as well as care of all people with mental disorders.

HEADINGS - Liver transplantation. Liver diseases. Mental disorders. Quality of life.

\section{INTRODUCTION}

Liver transplantation is the main therapeutic alternative for patients with chronic advanced liver disease ${ }^{(1)}$. The solid organ is a limited resource since the number of potential transplant recipients and the available donors are scarce, which results in a long wait. In this context, patients "most likely to succeed" must be carefully selected. The literature demonstrates high prevalence of psychiatric comorbidities on the waiting list for liver transplantation ${ }^{(2-5)}$. It is observed that $40 \%$ or more of the individuals enrolled in the liver transplant list have comorbid psychiatric disorders, which may negatively affect the outcome of the procedure and consequently the quality of life ${ }^{(6)}$. However, it is not clear in the literature if different causes of liver transplantation present distinct prevalence of mental disorder $^{(7)}$. Hepatitis $\mathrm{C}$ virus (HCV), alcoholic liver disease (ALD) and non-alcoholic steatohepatitis (NASH) are clinical conditions which are most associated with indication for liver transplantation ${ }^{(8)}$. Individuals with $\mathrm{HCV}$ often experience a six-fold increased risk of suicide and the onset of depressive symptoms and anxiety that result in decreased quality of life compared to the general population ${ }^{(9)}$.
ALD is one of the leading causes of chronic liver disease worldwide and has become a public health problem. This disease may range from simple steatosis, alcoholic hepatitis or steatohepatitis, progressive fibrosis, and eventually cirrhosis and/or hepatocellular carcinoma ${ }^{(10)}$. Alcohol consumption corresponds to $3.8 \%$ of overall mortality ${ }^{(11)}$.

This study aims to investigate whether patients in the liver transplant list showed differences in psychiatric characteristics, medical variables and quality of life according to the different liver diseases.

\section{METHODS}

This was a cross-sectional study which included patients, aged over 18 years, eligible for liver transplantation, enrolled in the Hepatology Service of Professor Edgar Santos University Hospital and Portuguese Hospital between 2010 and 2014. This study was approved by the local Institutional Review Board (MCO-UFBA - process number 14/2002) in accordance with the guidelines and norms of both the Brazilian Resolution 466/2012 and the Declaration of Helsinki of 2013 on research involving human beings. All participants provided written informed consent.

Declared conflict of interest of all authors: none

Disclosure of funding: This project was supported by the National Council of Technological and Scientific Development (CNPq): 462014/2014-2 - Edital Universal MCT/CNPQ 2014. The funders had no role in study design, data collection and analysis, decision to publish, or preparation of the manuscript.

1 Universidade Federal da Bahia, Faculdade de Medicina, Programa de Pós-graduação em Medicina e Saúde, Salvador, BA, Brasil. ${ }^{2}$ Universidade Federal da Bahia, Faculdade de Medicina, Salvador, BA, Brasil. ${ }^{3}$ Universidade Federal da Bahia, Serviço de Psiquiatria, Com-HUPES, Salvador, BA, Brasil.

Corresponding author: Lívia Guerreiro Costa. E-mail: liviaguerreiro@gmail.com 
Patients eligible for liver transplantation were analyzed in four different groups according to the clinical indication for transplantation. The first group - HCV - was formed by individuals infected with hepatitis $\mathrm{C}$, including individuals with hepatitis $\mathrm{B}$ coinfection. The second - ALD - had individuals with alcoholic liver cirrhosis. The third - HCV and ALD - included patients with both diagnoses and the fourth one - other indications - were composed of individuals nominated for transplantation due to other diseases, such as autoimmune hepatitis, NASH, Wilson's disease, hepatitis $\mathrm{B}$ and liver cancer.

Patients admitted to the hepatic transplant outpatient clinic were evaluated after insertion in the transplant list, submitted to the analysis of clinical and instrumental data for the diagnosis of psychiatric disorders and quality of life (QOL).

QOL was evaluated by the SF-36 self-assessment scale, which has eight quality of life domains: physical functioning, limitation of roles due to physical aspects, pain, general health, vitality, social functioning, emotional aspects and mental health. Each domain ranges from 0 to $100^{(12)}$.

The Mini International Neuropsychiatric Interview in its extended version - M.I.N.I. PLUS 5.0 $0^{(13)}$ was used to standardize the diagnostic method during the research. It is based on the DSM-IV criteria, the 4th version of the American Psychiatric Association Handbook on Mental Disorders, and the ICD-10 (World Health Organization, 1997). The structural organization of M.I.N.I. is composed of modules represented by letters of the alphabet which correspond to each category of diagnosis. There are key issues at the beginning of each module that represent the required criterion/ criteria for each diagnosis. The questions were answered with a simple "yes" or "no" and the questionnaire was applied by the trained researchers.

In accordance with the distribution of continuous variables data, they were compared by using Student's $t$-test, Mann-Whitney test and ANOVA. The categorical variables were compared using the chi-square test and Fisher's exact test (when necessary) and the powers of association between the independent variables as well as the outcomes studied were evaluated. Statistical analyses were performed using the Statistical Package for the Social Sciences software (version 21.0). Significance was defined as a value of $P<0.05$.

\section{RESULTS}

A total of 248 patients were included in the study: $193(77.8 \%)$ patients were male and $55(22.2 \%)$ female. Two hundred and seven patients were older than or equal to 40 years $(83.5 \%)$. One hundred and seventy-six patients were married or had a stable relationship, 38 were divorced or widowed and 32 were unmarried. With regard to the occupation, 170 patients were active professionals, 14 unemployed, 45 retired by age and 16 away by illness (TABLE 1 ).

Regarding the etiological diagnosis, 69 patients had hepatitis C, 64 presented alcoholic etiology, 36 had hepatitis C associated with alcoholic etiology and in 43 of them it was related toother etiologies (TABLE 2).

TABLE 2 also indicates the association of psychiatric comorbidities with demographic data, showing a higher prevalence of comorbidities among women (40\%) and in those under 40 years $(48.6 \%) P<0.05$.

TABLE 3 shows that, although there is no statistically significant difference, patients with hepatitis $\mathrm{C}$ present a higher prevalence of five out of nine psychiatric comorbidities: current major depres-
TABLE 1. Socio-demographic characteristics.

\begin{tabular}{lc}
\hline Variables & $\mathbf{N}(\%)$ \\
\hline Gender & $55(22.18)$ \\
Female & $193(77.82)$ \\
Male & \\
Age & $41(16.53)$ \\
$<40$ & $207(83.47)$ \\
$\geq 40$ & \\
Marital status & $32(12.90)$ \\
Single & $176(70.97)$ \\
Married/Stable relationship & $38(15.33)$ \\
Divorced/Widowed & \\
Occupation & $14(5.65)$ \\
Unemployed & $170(68.55)$ \\
Professionally active & $45(18.14)$ \\
Retired by age & $16(6.45)$ \\
Retired due to illness &
\end{tabular}

TABLE 2. Distribution of psychiatric comorbidities.

\begin{tabular}{|c|c|c|c|c|}
\hline \multirow{2}{*}{ Variables } & \multirow{2}{*}{ Total } & \multicolumn{2}{|c|}{$\begin{array}{c}\text { Psychiatric } \\
\text { comorbidities }\end{array}$} & \multirow{2}{*}{$P$ value } \\
\hline & & $\begin{array}{c}\text { Absence } \\
\text { N (\%) }\end{array}$ & $\begin{array}{c}\text { Presence } \\
\text { N }(\%)\end{array}$ & \\
\hline Gender & & & & $0.001 *$ \\
\hline Female & 55 & $33(60.0)$ & $22(40.0)$ & \\
\hline Male & 193 & $160(82.9)$ & $33(17.1)$ & \\
\hline Age & & & & $0.00 *$ \\
\hline$<40$ & 37 & $19(51.4)$ & 18 (48.6) & \\
\hline$\geq 40$ & 207 & $170(82.1)$ & $37(17.9)$ & \\
\hline Diagnosis etiology & & & & $0.170 * *$ \\
\hline $\mathrm{HCV}$ & 69 & $53(76.8)$ & $16(23.2)$ & \\
\hline ALD & 64 & $53(82.8)$ & $11(17.2)$ & \\
\hline HCV and ALD & 36 & $31(86.1)$ & $5(13.9)$ & \\
\hline Others & 43 & $28(65.1)$ & $15(34.1)$ & \\
\hline
\end{tabular}

HCV: hepatitis C virus. ALD: alcoholic liver disease. *Exact Fisher. **Analyzed through pearson chi-square.

sive episode, prior major depressive episode, anxiety disorders, illicit drug abuse and post-traumatic stress disorder. Patients with alcoholic etiology had a higher prevalence of alcohol abuse and/ or dependence throughout life. No patient was diagnosed with psychotic disorders.

Concerning the clinical data, we did not detect any statistically significant difference regarding the prevalence of diabetes mellitus and arterial hypertension in the different etiological groups.

No statistically significant difference was detected among the four etiological groups of liver disease in any of the eight domains studied regarding quality of life (TABLE 4). 
TABLE 3. Liver disease etiology and psychiatric and clinical comorbidity according to DSM-IV-TR through mini international neuropsychiatric interview.

\begin{tabular}{|c|c|c|c|c|c|c|}
\hline \multirow{2}{*}{ Psychiatric comorbidity } & \multirow{2}{*}{ Total } & \multicolumn{4}{|c|}{ Diagnosis etiology $\mathbf{N}(\%)$} & \multirow{2}{*}{$P$ value } \\
\hline & & $\mathrm{HCV}$ & ALD & HCV and ALD & Others & \\
\hline Past major depressive episode & 19 & $9(47.4)$ & $5(26.3)$ & $0(0.0)$ & $5(26.3)$ & $0.425 *$ \\
\hline Risk of suicide (moderate/high) & 8 & $1(12.5)$ & $1(12.5)$ & $1(12.5)$ & $5(62.5)$ & $0.058 *$ \\
\hline Anxiety disorders & 12 & $4(33.3)$ & $3(20.0)$ & $1(8.3)$ & $4(33.3)$ & $0.356^{*}$ \\
\hline Alcohol abuse/dependence & 90 & $1(1.1)$ & $54(60.0)$ & $35(38.9)$ & $0(0.0)$ & $0.00 *$ \\
\hline Adjustment disorder & 25 & $5(20.0)$ & $5(20.0)$ & $4(16.0)$ & $11(44.0)$ & $0.258 *$ \\
\hline Post traumatic stress disorder & 19 & $5(26.3)$ & $4(21.1)$ & $5(26.3)$ & $5(26.3)$ & $0.791 *$ \\
\hline Diabetes mellitus & 55 & $21(30.4)$ & $16(25)$ & $8(22.2)$ & $10(18.6)$ & $0.865 *$ \\
\hline Arterial hypertension & 47 & $16(23.2)$ & $15(23.4)$ & $7(19.4)$ & $9(20.9)$ & $0.839 *$ \\
\hline
\end{tabular}

HCV: hepatitis C virus; ALD: alcoholic liver disease. *Exact Fisher. **Analyzed through pearson chi-square.

TABLE 4. Liver disease etiology and quality of life.

\begin{tabular}{lcccccc}
\hline \multirow{2}{*}{ SF-36 Domains } & \multirow{2}{*}{ Total } & HCV & \multicolumn{2}{c}{ ALD } & HCV and ALD & Others \\
\cline { 3 - 7 } & & & \multicolumn{2}{c}{ Mean $(95 \%$ confidence interval for mean) } & \\
\hline $\begin{array}{l}\text { Physical } \\
\text { functioning }\end{array}$ & $68.66(64.58-72.74)$ & $69.42(62.59-76.25)$ & $66.71(58.64-74.78)$ & $69.72(55.91-83.54)$ & $69.90(62.27-77.54)$ & 0.930 \\
$\begin{array}{l}\text { Physical role } \\
\text { functioning }\end{array}$ & $34.57(29.00-40.14)$ & $40.58(29.01-52.15)$ & $28.93(20.40-37.46)$ & $31.94(14.46-49.43)$ & $35.10(24.40-45.80)$ & 0.408 \\
Bodily pain & $67.78(64.15-71.40)$ & $66.75(60.66-72.85)$ & $69.01(62.46-75.56)$ & $65.28(50.90-79.66)$ & $68.33(60.87-75.78)$ & 0.934 \\
General health & $59.49(56.62-62.37)$ & $62.87(58.13-67.61)$ & $60.50(55.90-65.10)$ & $62.22(51.86-72.58)$ & $52.71(46.03-59.40)$ & 0.053 \\
Vitality & $64.32(59.62-69.03)$ & $66.91(55.11-78.71)$ & $63.77(58.46-69.08)$ & $71.11(58.02-84.20)$ & $59.33(51.97-66.68)$ & 0.532 \\
$\begin{array}{l}\text { Social role } \\
\text { functioning }\end{array}$ & $70.93(66.98-74.88)$ & $70.11(63.01-77.21)$ & $69.29(62.39-76.18)$ & $76.39(62.92-89.85)$ & $72.36(64.16-80.55)$ & 0.793 \\
$\begin{array}{l}\text { Emotional role } \\
\text { functioning }\end{array}$ & $80.86(72.72-89.00)$ & $83.09(75.49-90.69)$ & $82.86(61.18-104.54)$ & $83.33(66.04-100.63)$ & $74.36(63.39-85.33)$ & 0.846 \\
Mental health & $81.76(77.69-85.83)$ & $79.88(75.21-84.56)$ & $84.00(74.99-93.01)$ & $86.89(79.61-94.17)$ & $79.69(70.06-89.33)$ & 0.694 \\
\hline
\end{tabular}

HCV: hepatitis $\mathrm{C}$ virus; ALD: alcoholic liver disease. *ANOVA.

\section{DISCUSSION}

The present study demonstrates high prevalence of mental disorders in individuals with indication for liver transplantation $^{(3)}$. Nevertheless, we did not find any difference for psychiatric comorbidity prevalence among the four different groups related to the clinical indication for transplantation. According to the data obtained, $126(50.8 \%)$ patients on the transplant waiting list had diagnosis of at least one current or lifelong mental disorder. When alcohol abuse/dependence was excluded, the prevalence was $25.8 \%$. These data are considered high when compared to the prevalence of mental disorders in the world population. A study conducted with both systematic review and meta-analysis revealed that $17.6 \%$ of 650.000 people in 59 countries experienced mental disorder during the past 12 months and $29.2 \%$ of 450.000 in 38 countries had experience of at least one episode of lifelong mental disorder ${ }^{(14)}$.

It is demonstrated that the hepatitis $\mathrm{C}$ transmission in Brazil is less associated with the use of injectable drugs in comparison with other countries ${ }^{(15)}$. Consequently, the rate of substance abuse and dependence in hepatitis $\mathrm{C}$ subjects was not significant with only five $(4.8 \%)$ patients of the patients in the group.

There was no diagnosis of psychotic disorders in the sample studied. We believe that this occurs due to selection bias coming from a widespread belief among health professionals, especially the non-trained in mental health, that this group of patients are worse adherents to the treatment. This is an important point that should be evaluated and discussed among transplant teams and also mental health teams for proper assessment and judgment whether or not psychotic disorder is a factor for treatment exclusion. It is possible that the low number of drug users in the study group is also explained by early exclusion.

Previous studies have evaluated the association between the etiology of liver disease and psychiatric comorbidities. Saracino et al. ${ }^{(16)}$ studied 120 patients with advanced liver disease (52\% with $\mathrm{HCV}, 15 \%$ with ALD and $9.2 \%$ with NASH) and detected prevalence of $51.3 \%$ of psychiatric comorbidities (anxiety, depression and post-traumatic stress disorder).

Madan et al. ${ }^{(17)}$ evaluated 108 patients: $36.1 \% \mathrm{HCV}, 11.1 \%$ ALD, $46.3 \% \mathrm{HCV}$ and ALD and $6.5 \%$ NASH and reported that $40 \%$ of the patients underwent psychiatric follow-up. Rogal et al. ${ }^{(4)}$ evaluated 179 patients, $32.9 \% \mathrm{HCV}, 13.4 \% \mathrm{ALD}, 14.5 \% \mathrm{HCV}$ and ALD, and $103(57 \%)$ individuals were detected with depression and/or anxiety. Some studies have indicated that individuals with HCV tend not only to have a lower quality of life than the general population but 
also to have a high presence of psychiatric symptoms associated with their own course $\mathrm{e}^{(9,15,18,19,20)}$. According to the present data, the patients assessed presented different serious liver conditions but with no statistically significant difference in relation to quality of life.

The main limitation of this study is the limited sample size, once it was divided into four groups. Another limitation is the absence of assessment for personality disorders. Finally, a possible critical limitation in this study is that the most severe psychiatric patients are not even able to get on the waiting list for liver transplantation, thus promoting interpretation bias.

\section{CONCLUSION}

A high prevalence of psychiatric disorders was found among all clinical conditions most associated with the indication of liver transplantation. Detailed evaluation of mental health by specialized team is required, minimizing the exclusion of patients with possibility of adherence and therapeutic success. It is noteworthy that transplantation is the only therapeutic possibility for patients with advanced hepatic insufficiency, being, therefore, fundamental the implantation of psychiatric/psychological support, guaranteeing to the patient adequate evaluation of his mental health condition before the decision to exclude this possibility of treatment.

\section{ACKNOWLEDGEMENTS}

The authors thank all the patients who agreed to be included in this study for their cooperation. We are also grateful to Denise Pinheiro for proofreading, Liana Codes, Maria Isabel Schinoni, André C. Lyra, Jorge Luiz Andrade-Bastos and Raymundo Paraná for the review and suggestions, Alessandra de Castro and Maria Auxiliadora Evangelista for the help in collecting the data.

\section{Authors' contribution}

Jesus-Nunes AP, Morais-de-Jesus M, Marback RF and Quarantini LC were responsible for the psychological and psychiatric evaluation of the patients. Guerreiro-Costa LNF and Araújo-Filho JEO made the evaluation of the clinical data. All authors participated in the analysis of the results and writing of the manuscript.

\section{Orcid}

Lívia N F Guerreiro Costa. Orcid: 0000-0002-2367-0870.

José Edson O Araújo Filho. Orcid: 0000-0002-6283-9579.

Roberta Ferrari Marback. Orcid: 0000-0003-3870-8963.

Ana Paula Jesus Nunes. Orcid: 0000-0002-0389-1940.

Mychelle Morais de Jesus. Orcid: 0000-0003-3856-3776.

Lucas C Quarantini. Orcid: 0000-0002-8807-8464.

Guerreiro-Costa LNF, Araújo-Filho JEO, Marback RF, Jesus-Nunes AP, Morais-de-Jesus M, Quarantini LC. Desordens mentais e qualidade de vida em pacientes em lista de espera para realização de transplante de fígado. Arq Gastroenterol. 2019;56(4):339-43.

RESUMO - Contexto - O transplante hepático é a principal alternativa terapêutica para pacientes com doença hepática avançada. Esses pacientes apresentam alta prevalência de comorbidades psiquiátricas que podem interferir negativamente nos desfechos clínicos e qualidade de vida. Não está claro na literatura se as diferentes etiologias de doença hepática têm a mesma prevalência de transtornos psiquiátricos. Objetivo - O objetivo deste estudo foi investigar se os pacientes na lista de transplante hepático apresentavam diferenças nas variáveis psiquiátricas, variáveis clínicas e qualidade de vida em diferentes grupos etiológicos. Métodos - Estudo transversal que avalia as comorbidades psiquiátricas e clínicas e as variáveis de qualidade de vida por meio da aplicação de questionários e instrumentos validados em 248 pacientes inseridos em lista de espera para transplante hepático no período de 2010 a 2014, acompanhados no Hospital Universitário Professor Edgard Santos e Hospital Português (Salvador, BA). Os pacientes foram avaliados através da aplicação do Mini International Neuropsychiatric Interview (M.I.N.I. PLUS 5.0) e Medical Outcomes Short-Form Health Survey (SF-36). Resultados - A etiologia da doença hepática mais prevalente foi o vírus da hepatite C. Prevalência de 50,8\% de pelo menos um transtorno mental foi identificada. Quando o abuso/dependência de álcool foi excluído, a prevalência foi de $25,8 \%$. A saúde mental não apresentou diferença estatisticamente significante nos diversos grupos etiológicos. Maior prevalência de comorbidades psiquiátricas foi detectada entre mulheres e menores de 40 anos. Não foram detectados casos de transtornos psicóticos, possivelmente pela não inclusão destes pacientes na lista. Não houve diferença nos domínios de qualidade de vida nos diferentes grupos etiológicos. Conclusão - Uma alta prevalência de transtornos psiquiátricos foi encontrada nos pacientes com todas as condições clínicas mais associadas à indicação de transplante hepático. Chama a atenção a ausência de pacientes com transtornos psicóticos, o que sugere que possivelmente o transplante não tem sido indicado para esse grupo de pacientes. Por esses motivos, os profissionais que cuidam de candidatos ao transplante de fígado devem ser altamente vigilantes para a presença de transtornos mentais, independentemente da etiologia da doença hepática. A atenção especializada é recomendada para os pacientes com transtornos mentais, com minimização de exclusão precoce da lista de pacientes sem outras possibilidades terapêuticas.

DESCRITORES - Transplante de fígado. Hepatopatias. Transtornos mentais. Qualidade de vida. 


\section{REFERENCES}

1. Mies S. Transplante de Fígado. Revista da Associação Médica Brasileira.1998;44:127-34.

2. Maldonado JR, Sher Y, Lolak S, Swendsen H, Skibola D, Neri E, et al. The Stanford Integrated Psychosocial Assessment for Transplantation: A Prospective Study of Medical and Psychosocial Outcomes. Psychosom Med. 2015;77:1018-30.

3. Grover S, Sarkar S. Liver transplant-psychiatric and psychosocial aspects. J Clin Exp Hepatol. 2012;2:382-92.

4. Rogal SS, Landsittel D, Surman, Chung RT, Rutherford A. Pretransplant depression, antidepressant use, and outcomes of orthotopic liver transplantation. Liver Transp. 2011;17:251-60.

5. Martins PD, Sankarankutty AK, Silva Ode C, Gorayeb R. Psychological distress in patients listed for liver transplantation. Acta Cir Bras. 2006;21:40-3.

6. Schneekloth TD, Jowsey SG, Biernacka JM, Burton MC, Vasquez AR, Bergquist T, et al. Pretransplant psychiatric and substance use comorbidity in patients with cholangiocarcinoma who received a liver transplant. Psychosomatics. 2012;53:116-22

7. Heinrich TW, Marcangelo M. Psychiatric issues in solid organ transplantation. Harv Rev Psychiatry. 2009;17:398-406.

8. Stilley CS, DiMartini AF, Tarter RE, DeVera M, Sereika S, Dew MA, et al. Liver transplant recipients: individual, social, and environmental resources. Prog Transplant. 2010;20:68-74.

9. Golden J, O'Dwyer AM, Conroy RM. Depression and anxiety in patients with hepatitis $\mathrm{C}$ : prevalence, detection rates and risk factors. Gen Hosp Psychiatry. 2005;27:431-8.

10. O'Shea RS, Dasarathy S, McCullough AJ; Alcoholic liver disease. Hepatology. 2010;51:307-28.

11. Rehm J, Mathers C, Popova S, Thavorncharoensap M, Teerawattananon Y, Patra J. Global burden of disease and injury and economic cost attributable to alcohol use and alcohol-use disorders. Lancet. 2009;373:2223-33.
12. Ciconelli R, F.M., Santos W, Meinão I, Quaresma M. Tradução para a língua portuguesa e validação do questionário genérico de avaliação de qualidade de vida SF-36 (Brasil SF-36). Rev Bras Reumatol. 1999;39(3).

13. Amorim, P., Mini International Neuropsychiatric Interview (MINI): validação de entrevista breve para diagnóstico de transtornos mentais. Revista Brasileira de Psiquiatria. 2000;22:106-15.

14. Steel Z, Marnane C, Iranpour C, Chey T, Jackson JW, Patel V, Silove D. The global prevalence of common mental disorders: a systematic review and meta-analysis 1980-2013. Int J Epidemiol. 2014;43:476-93.

15. Batista-Neves SC, Quarantini LC, de Almeida AG, Bressan RA, Lacerda AL, deOliveira IR, et al. High frequency of unrecognized mental disorders in HCV-infected patients. Gen Hosp Psychiatry. 2008;30:80-2. (era 10 passou a ser 15)

16. Saracino RM, Jutagir DR, Cunningham A, Foran-Tuller KA, Driscoll MA, Sledge WH, Emre SH, Fehon DC. Psychiatric Comorbidity, Health-Related Quality of Life, and Mental Health Service Utilization Among Patients Awaiting Liver Transplant. J Pain Symptom Manage. 2018;56:44-52.

17. Madan A Borckardt JJ, Balliet WE, Barth KS, Delustro LM, Malcolm RM, Koch D, Willner I, Baliga P, Reuben A. Neurocognitive status is associated with all-cause mortality among psychiatric, high-risk liver transplant candidates and recipients. Int J Psychiatry Med. 2015;49:279-95.

18. Kristiansen MG, Lochen ML, Gutteberg TJ, Mortensen L, Eriksen BO, Florholmen J. Total and cause-specific mortality rates in a prospective study of community-acquired hepatitis C virus infection in northern Norway. J Viral Hepat. 2011;18:237-44. Era 11 passou a 18

19. Johnson ME, Fisher DG, Fenaughty A, Theno SA. Hepatitis C virus and depression in drug users. Am J Gastroenterol. 1998;93:785-9.

20. Rifai MA, Gleason OC, Sabouni D. Psychiatric care of the patient with hepatitis C: a review of the literature. PrimCare Companion J ClinPsychiatry. 2010;12:PCC.09r00877. 